\title{
The Analysis of the Use of Outsourcing Services in Logistics by Czech Manufacturing Companies
}

\author{
- Hrušecká Denisa, Macurová Lucie, Juričková Eva, Kozáková Leona
}

\begin{abstract}
This research analyses logistics outsourcing services from the viewpoint of client companies (manufacturing companies). The main goal is to show how intensively various logistics outsourcing services are used by Czech manufacturing companies in comparison with other world regions, and which areas of logistics outsourcing should be considered more seriously in order to increase logistic efficiency. The study is based on a quantitative and qualitative investigation of Czech manufacturing companies. Firstly, the brief overview of the present situation in the Czech market is presented. It is based on survey data. The results of this quantitative study are compared with global research activities, especially with the 2013 Third-Party Logistics Study carried out by Capgemini Consulting Company. Next, results of the qualitative investigation are discussed. This part describes the experience of four selected Czech manufacturing companies with logistics outsourcing, the main problems they face in this area and their future plans and expectations. The present study is part of a more complex research currently being carried out by the authors.
\end{abstract}

Keywords: Logistics, Outsourcing, Third-Party Logistics, Transportation, Warehousing, Supply Chain Management

JEL Classification: M19, L99

\section{INTRODUCTION}

The environment of today's manufacturing companies is very dynamic and highly competitive. Many enterprises are aiming to gain a share of the global market and take advantage of sourcing efficiencies and rapid reaction capability of production processes to changing market conditions. This changing market environment causes increasing complexity of production processes and the whole supply chain management becomes more and more sophisticated. For many companies, the gap is between what they want to accomplish and what they can do in-house. Therefore, the role of outsourcing is still growing (Aktas et al., 2011).

Corbett (2004) describes outsourcing as a phenomenon that has skyrocketed in recent years. However, it is not a new phenomenon; outsourcing as a practice originated in the 1950s and in the 1980s it was first adopted in organisations as a strategy (Hätönen \& Eriksson, 2009). This paper focuses on outsourcing logistics services, especially outsourcing some logistics activities to so-called third-party logistics providers (3PLs). According to Capgemini's annual broad 3PLs study (2013), the aggregate global revenues for the 3PL sector continue to rise and more than 65 $\%$ of shippers are still increasing their use of 3PL services rather than returning to insourcing some 3PL services. 
There are a lot of reasons for logistics outsourced. Decisions to use logistic outsourcing services can be influenced by the region, company size, industry type, occupied markets or many others (Hong et al., 2004). Grossler et al. (2013) discovered that while companies that outsource internationally focus on achieving cost benefits, companies that outsource domestically focus on achieving capacity flexibility.

In general, logistics outsourcing can be used at one of the following stages (Idnes, 2013):

\section{- 2PL (second-party logistics)}

This form of logistics outsourcing is suitable for small companies with a very simple supply chain. The manufacturing company orders some logistics services from a specialised firm (for example transport).

\section{- 3PL (third-party logistics)}

As Third-Party Logistics (3PL) are termed organisations offering external logistic services such as transportation, distribution services, warehousing, packaging and many others. This branch has become very popular with manufacturing companies which need to decrease their logistic costs or to implement some verified strategies of supply chains. Third-Party Logistic providers gain more expertise and, therefore, their level of service can bring more value to customer companies. This type of logistics outsourcing is the most often used in practice.

\section{- 4PL (fourth-party logistics)}

It is the closest type of cooperation, in which case a 4PL provider takes responsibility for the whole supply chain optimisation and helps to manage individual subordinate 3PL providers. This type of logistics outsourcing is used especially by large supranational organisations.

The main goal of this paper is to describe the situation of the Czech market in the area of logistics outsourcing from the viewpoint of manufacturing companies. We also compare our results with those of the global 3PL study conducted by Capgemini (2013), and discuss some differences and especially problems of Czech manufacturing companies. The evaluation of selected logistics activities and their impact on a company's performance was part of a large research study conducted in 2009 by Tomas Bata University in Zlín under the Czech Science Foundation. During this study, respondents were also asked about the position of the logistics departments in their organisation structure. While in 2001 almost $6 \%$ of Czech companies did not have their own logistics department and used only 3PLs provider services, in 2009 this number decreased to less than $1 \%$ (Bobák \& Pivodová, 2011). However, the results mentioned above do not mean that the usage of 3PLs services has decreased as well; the study did not discuss this area separately and, therefore, the present paper describes only this particular field of logistics.

In our study, we focus on examining potential dependences between areas of logistic outsourcing and (outsourced logistic activities) and expected contributions to logistic efficiency. Our aim is to find out an answer to which activities should be outsourced and under which conditions or what are the main barriers to using outsourcing services in logistic area more intensively. A lot of research studies are focused on the relationships between the provider and consumers of logistic outsourcing services, decision-making procedures or global trends as Stojanovic (2012) 
confirms. However, there are just a few studies investigating the relationship between different outsourced logistic activities and required financial benefits while this kind of research can be useful even for business practice. One of the most similar ones is a survey of Richard Wilding and Rein Juriado (2004) which investigates customer perceptions on the most important logistics outsourcing decisions: why to outsource, what to outsource and how to manage it. The results of their study showed that over two thirds of manufacturing companies manage at least one logistics function with a mixed system combining the use of in-house and third party facilities.

\section{ECONOMIC ASPECTS AND MEASURABLE BENEFITS OF LOGISTIC OUTSOURCING}

The major problem for many companies is how to measure the strategic or economic value that logistic outsourcing can offer. Several authors, researchers, managers and other interested parties have tried to answer this question and create a list of key indicators. However, their points of view are quite different. While some claim that logistic outsourcing must always bring some cost reduction, others highlight its strategic value in terms of fulfilling goals that are not always directly concerned with financial targets. As Hsaio et al. (2010) confirm, most studies of logistics outsourcing are focused on cost reduction and only a few of them report on service and strategic benefits.

In general, outsourcing non-core processes (as logistics is for the majority of manufacturing companies) decreases capital investment requirements, which in turn drives more of the company's profit into return on assets. Mojsilović, Ray, Lawrence and Takriti (2007) proved, in their study, that outsourcing does have a quantifiable impact on a company's finances, but they also admit that outsourcing decisions are extremely complex and influenced by both quantitative and qualitative factors.

Marshall, McIvor and Lamming (2007) conducted a study on the experience of three telecommunication companies with outsourcing some non-core processes (logistic, testing, calibration, etc.). In all cases, outsourcing was regarded as a major strategy for achieving required flexibility, which helped to place the companies in a better position to react rapidly to market changes. However, higher flexibility is only one of the key logistic service performance indicators. The analysis of outsourcing from a network point of view conducted by Gadde and Hulthén (2009) showed that the outsourcing of logistics is not only about moving some logistic activities from one organisation to another, as it affects many other activities and brings some new approaches to resource management and relationships between supply chain members.

Bali et al. (2015) emphasise the role of third party logistics partners in logistics outsourcing and its measurable benefits in their study. The success of logistics outsourcing is highly influenced by the right selection of logistics outsourcing provider as also Wan et al. (2015) confirmed in their research paper. Therefore, the selection of outsourcing partner become a strategic decision making problem and must be considered really seriously.

Bajec (2013) conducted the survey within Slovenian logistics providers and he found out that they are not mature enough for more intelligent means of logistic outsourcing yet. His suggested intelligent logistics outsourcing model should offer more innovative solutions that should increase benefits of logistic outsourcing for its customers. He also agrees that the success of 
logistics outsourcing is really influenced by the quality of third party logistic partner and used technologies and innovations.

\section{SOME RISKS AND NEGATIVES OF LOGISTICS OUTSOURCING}

There are many potential benefits from logistic outsourcing. However, there are also huge potential risks associated with it. Bjornar et al. (2008) argue the fact that the evolution of gradually more complex supply chains makes decisions about logistics outsourcing more difficult. Their empirical analysis showed that it is not always beneficial to outsource some activities what is proved by an example from the Norwegian oil and gas industry explain in their paper.

Li-jun (2012) describes a control model of logistics outsourcing risks which includes the following five basic types or categories:

- Contract risk - the risk that a third party logistic provider cannot fulfil all requirements in required quality or required time.

- Management risk - this type of risk can be caused by the difference between the management methods and the culture of the company used by the provider and client.

- Information risk - the risk of poor quality information sharing which can result in serious problems and dramatic losses.

- Market risk - this type of risk refers to market fluctuations such as labour price, raw materials price, the changes in customer demand, etc.

- Financial risk - financial risk means that the real return on investment of logistic outsourcing is lower than the expectation.

Many authors deal with logistics risk from various viewpoints. For example, Tsai et al. (2012) examined the links between three types of risks in logistics outsourcing: relationship risk, asset risk and competence risk. They found that relationship risk leads to both asset risk and competence risk.

Most important is to try to prevent potential risks. Sun and Zheng (2008) carried out a research study in which they tried to create a model of early-warning logistic outsourcing risks based on four phases introduced in their paper. However, the practical implementation of such results is always very difficult and requires a high level of experience, time and patience.

\section{RESEARCH STRATEGY AND METHODS}

The main objective of our study is to determine how frequently Czech manufacturing companies use outsourcing services in logistics, which particular areas are the most often outsourced and what are the main reasons for logistics outsourcing. We also propose to find out whether there is a correlation between the main reasons for outsourcing in logistics and the most often outsourced logistic activities. The results of our study are consequently accompanied by qualitative investigation in order to find out the answer to which activities should be outsourced and under which conditions to increase logistic efficiency. 
A combination of quantitative and qualitative investigations was chosen to undertake the research. In the first phase, we conducted a very simple survey based on quantitative research to get a basic overview of the current situation of the Czech market. We asked our respondents whether they used outsourcing services in logistics, which specific processes were most often outsourced and what were their positive or negative experiences with logistic outsourcing.

We used European classification according to the number of persons employed, and by which enterprises are classified into the following groups (Eurostat, 2013):

- Micro enterprises (with less than 10 persons employed)

- Small enterprises (from 10 to 49 persons employed)

- Medium-sized enterprises (from 50 to 249 persons employed)

- Large enterprises (with 250 or more persons employed)

Sometimes, we mention the SMEs category in our study. This category contains micro, small and medium sized enterprises (enterprises with less than 250 persons employed). The sample of our quantitative investigation included 44 companies of which 30 were from the SMEs segment (Small and Medium sized Enterprises).

The second phase of our research was conducted as a qualitative study in the form of detailed structured interviews with the logistics managers of selected companies. This qualitative approach allowed the researchers to analyse relationships and discuss the most important findings which are not possible via the quantitative approach alone. It was focused on four Czech manufacturing companies including two automotive plastic parts producers, one mechanical engineering company and one important Czech tyre producer.

\section{RESULTS}

The following sub-sections summarise the results of both quantitative and qualitative investigation. For data credibility, the respondents were all logistic managers, production managers or other people responsible for the company's logistics.

\subsection{Quantitative Investigation}

The sample of the questionnaire-based quantitative investigation consisted of 44 logistics managers or other representatives of Czech manufacturing companies (from automotive, engineering, plastic industry and electronic), of which only 36 (a little less than $82 \%$ ) stated that they outsource some logistic activities. Outsourcing services in logistics are most often used by large enterprises where the positive answer has appeared in $100 \%$ cases. However, surprisingly, in the case of small enterprises the usage of outsourcing is higher ( $80 \%)$ than in the case of mediumsized enterprises (55\%). Therefore, it is not possible to offer a general statement that the usage of outsourcing services in logistics increases with the size of the company. Micro enterprises were completely excluded from the research as they indicated that did not use logistics outsourcing in any area. 
The following chart (Fig. 1) shows which logistics activities are the most often outsourced. Respondents were allowed to choose more than one answer.
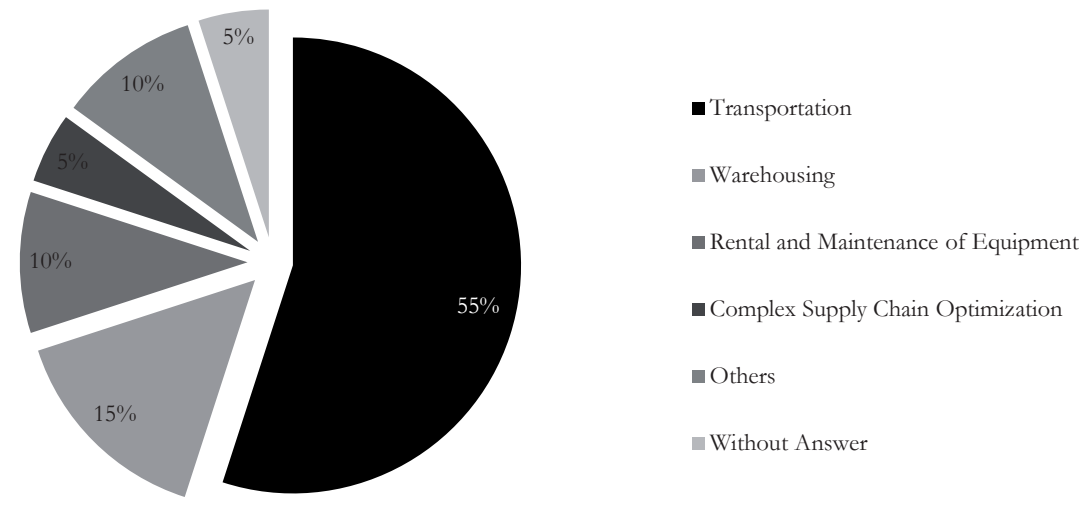

Fig. 1 - Areas of Logistics Outsourcing. Source: Authors' own

Breakdown of the areas of logistics outsourcing according to the size of the company is presented in the next table (Tab. 1).

Tab. 1 - Areas of logistics outsourcing according to the company size. Source: Authors' own

\begin{tabular}{|l|l|l|l|l|}
\hline $\begin{array}{l}\text { The table includes results in percentage of all } \\
\text { respondents in several categories }\end{array}$ & Small & $\begin{array}{l}\text { Medium- } \\
\text { sized }\end{array}$ & Large & Total \\
\hline Transportation & 60 & 66 & 45 & 55 \\
\hline Warehousing & 0 & 17 & 22 & 15 \\
\hline Fleet management & 20 & 17 & 11 & 10 \\
\hline Complex supply chain optimisation & 0 & 0 & 11 & 5 \\
\hline Others & 20 & 0 & 11 & 10 \\
\hline
\end{tabular}

The table above (Tab. 1) shows the most often outsourced logistics activities classified by the company's size. According to these results, no clear correlation is evident at first sight. The potential dependence between the company's size and outsourced logistics activities was statistically verified using Pearson's chi-square test and Fisher's exact test. For the purpose of these tests, small and medium-sized enterprises were grouped into one category - SMEs (Small and Medium sized Enterprises).

$\mathrm{H} 0$ hypothesis ( $\mathrm{H} 0$ : variables are independent) was tested at the significance level of $1 \%$. In both cases, we failed to reject H0 (Pearson's chi-square test: $\mathrm{p}$-value $=0,3483$, Fisher's exact test: $\mathrm{p}$ value $=0,4642)$. Even the Fisher's exact test with simulated p-value (based on 5000 replicates) failed to reject the null hypothesis as the $\mathrm{p}$-value ( $\mathrm{p}$-value $=0,5361) \geq \alpha(\alpha=0,01)$. The results of statistical testing did not show any correlation between the variables, which means that we 
do not have any evidence for the statement that the most often outsourced logistics activities are dependent on the company's size and vice versa.

When we compare our results with the results of Capgemini's 2013 Third-Party Logistics Study (2013), which is a more extensive study focused on different regions of the world, we observe that the proportion in the most frequently outsourced logistics activities is quite different (see Tab. 2). It should be noted that the Capgemini study is more extensive and includes more detailed classification of outsourced logistics activities. Therefore, only areas that should be compared with our research were selected.

Tab. 2 - Areas of logistics outsourcing: Comparison with the 2013 Third-Party Logistics Study and other world regions. Source: Authors' own and Campgemini, 2013

\begin{tabular}{|c|c|c|c|c|c|c|}
\hline \multirow{2}{*}{$\begin{array}{l}\text { The table includes } \\
\text { results in percentage }\end{array}$} & \multirow{2}{*}{$\begin{array}{l}\text { Czech } \\
\text { Republic }\end{array}$} & \multicolumn{5}{|c|}{2013 Third-Party Logistics Study } \\
\hline & & Europe & $\begin{array}{l}\text { North } \\
\text { America }\end{array}$ & $\begin{array}{l}\text { Latin } \\
\text { America }\end{array}$ & $\begin{array}{l}\text { Asia- } \\
\text { Pacific }\end{array}$ & $\begin{array}{l}\text { All } \\
\text { Regions }\end{array}$ \\
\hline Transportation & 55 & 81 & 67 & 82 & 79 & 76 \\
\hline Warehousing & 15 & 72 & 61 & 59 & 51 & 63 \\
\hline Fleet management & 10 & 8 & 8 & 9 & 8 & 8 \\
\hline $\begin{array}{l}\text { Complex supply chain } \\
\text { optimisation }\end{array}$ & 5 & 17 & 14 & 9 & 9 & 10 \\
\hline Others & 10 & $>50$ & $>50$ & $>50$ & $>50$ & $>50$ \\
\hline
\end{tabular}

As can be seen from the above table (Tab. 2), the usage of logistics outsourcing by Czech manufacturing companies is lower in almost all areas in comparison with other regions, expect the fleet management. The causes of these results are discussed in the next section (qualitative study).

The second important question of the quantitative investigation is related to reasons for which our companies decide to outsource some logistics activities. The next picture (Fig. 2) shows that there are two basic reasons: cost reduction and a lack of resources.

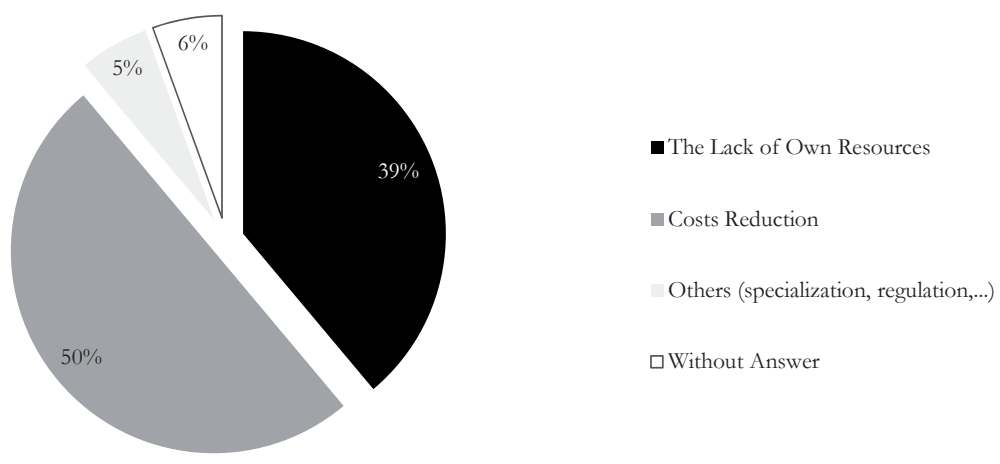

Fig. 2 - Reasons for Logistics Outsourcing. Source: Authors' own 
The proportional difference between the above mentioned reasons for logistic outsourcing is very similar for small, medium-sized or large enterprises. The only finding that can be concluded is that large enterprises prioritise cost reduction (over $60 \%$ ) as a major benefit from logistics outsourcing. Very similar results were gained also in Capgemini's 2013 Third-Party Logistics Study (2013), where shippers reported significant savings from logistics cost reductions (around $15 \%$ ), inventory cost reductions (around 8\%) and logistics fixed asset reductions (around 26 $\%$ ). More than $70 \%$ of shippers who were questioned expressed their satisfaction with 3PLs relationships.

One of the objectives of the research was to determine whether there is a correlation between the main reasons for outsourcing in logistics and the most often outsourced logistic activities at the significance level of $1 \%$. In order to determine the dependence, the frequency table with absolute frequency values (Tab. 3) and the table with relative frequency values (Tab. 4) were used.

Tab. 3 - The correlation between the main reasons for outsourcing in logistics and the most often outsourced logistic activities - absolute frequency values. Source: Authors' own

\begin{tabular}{|l|c|c|c|c|}
\hline \multirow{2}{*}{$\begin{array}{l}\text { Areas of Logistic Out- } \\
\text { sourcing }\end{array}$} & \multicolumn{4}{|l|}{ The Main Reasons for Logistic Outsourcing } \\
\cline { 2 - 5 } & $\begin{array}{c}\text { The lack of } \\
\text { own capacities }\end{array}$ & Costs reduction & $\begin{array}{c}\text { Experiences, } \\
\text { specialisation }\end{array}$ & Total \\
\hline Transportation & 9 & 18 & 0 & 27 \\
\hline Warehousing & 7 & 1 & 0 & 8 \\
\hline $\begin{array}{l}\text { Rental and maintenance } \\
\text { of equipment }\end{array}$ & 2 & 2 & 2 & 6 \\
\hline $\begin{array}{l}\text { Complex supply chain } \\
\text { optimisation }\end{array}$ & 18 & 2 & 1 & 3 \\
\hline Total & & 23 & 3 & 44 \\
\hline
\end{tabular}

Tab. 4 - The correlation between the main reasons for outsourcing in logistics and the most often outsourced logistic activities - relative frequency values. Source: Authors' own

\begin{tabular}{|c|c|c|c|c|}
\hline \multirow[b]{2}{*}{$\begin{array}{c}\text { Areas of Logistic Out- } \\
\text { sourcing }\end{array}$} & \multicolumn{3}{|c|}{ The Main Reasons for Logistic Outsourcing } & \multirow[b]{2}{*}{ Total } \\
\hline & $\begin{array}{c}\text { The lack of own } \\
\text { capacities }\end{array}$ & Costs reduction & $\begin{array}{l}\text { Experiences, } \\
\text { specialisation }\end{array}$ & \\
\hline Transportation & 11,045455 & 14,113636 & 1,840991 & 27 \\
\hline Warehousing & 3,272727 & 4,181818 & 0,5454545 & 8 \\
\hline $\begin{array}{c}\text { Rental and maintenance } \\
\text { of equipment }\end{array}$ & 2,454545 & 3,136364 & 0,490909 & 6 \\
\hline $\begin{array}{l}\text { Complex supply chain } \\
\text { optimisation }\end{array}$ & 1,227273 & 1,568182 & 0,2045455 & 3 \\
\hline Total & 18 & 23 & 3 & 44 \\
\hline
\end{tabular}




\section{HO: Areas of logistic outsourcing and the main reasons for outsourcing are independent.}

\section{H1: Areas of logistic outsourcing and the main reasons for outsourcing are not independent.}

Critical value (percentile) for the chi-square distribution with 6 degrees of freedom at the significance level of $1 \%$ is 16,81 . Since the calculated chi-square value $(21,73)$ is more than the critical value $(16,81)$, we cannot accept the null hypothesis. However, because the sample size is relatively small, the chi-squared approximation may be incorrect. Therefore, we used also the Pearson's chi-squared test with simulated p-value (based on 5000 replicates) to test the null hypothesis at the same significance level $(1 \%)$. As the calculated p-value $(0,003799)$ is less than the significance level $(0,01)$, we cannot accept the null hypothesis as in the first case. Thus, we conclude that there is a relationship between the areas of logistic outsourcing and the main reasons for outsourcing selected logistic activities.

Even though the chi-square test showed statistical significance between our two variables, the relationship may not be substantively important. Therefore, the Pearson's contingency coefficient was used as a measure of the relative (strength) of an association between the areas of logistic outsourcing and the main reasons for outsourcing selected logistic activities (see equations 1 and 2).

$$
\begin{aligned}
& P=\sqrt{\frac{X^{2}}{X^{2}+n}} ; P \in\langle 0 ; 1) \\
& P=\sqrt{\frac{21,73}{21,73+44}}=0,575
\end{aligned}
$$

The Pearson's coefficient is always more than zero and less than one. In our case, the calculated value of Pearson's coefficient is somewhere in the middle between zero and one, which means that the statistical significance between our two variables is average.

\subsection{Qualitative Investigation}

Qualitative investigation was realised in the form of an interview with logistics managers from four selected manufacturing companies (large and middle sized). It was very surprising that only one of them considered logistics outsourcing as an important trend which had great potential for improvements. All other respondents said that the most important questions in the logistics area concern advanced technologies such as automation, RFID technologies and others, implementing internal lean principles, information technologies, etc. They admitted that they did not handle outsourcing services in the logistics area and only outsourced activities for which they did not have the capacity. Of course, the logistics costs are an important criterion for deciding which activities should be outsourced. However, they often only think about basic logistics services such as transportation or sometimes warehousing, and they ignore many other services offered by 3PLs or 4PLs providers.

According to Capgemini's study (2013), the 3PL sector continues to grow and more and more shippers are increasing their use of 3PL services instead of returning to insourcing. In the case of the Czech Republic, manufacturing companies still do not take advantage of enough opportunities for outsourcing, and they focus only on basic ones such as transportation or warehousing. 


\section{DISCUSSION AND CONLUSION}

The paper analysed logistics outsourcing services from the point of view of Czech manufacturing companies. The results of a survey based investigation were compared with global trends. This comparison showed that Czech companies use logistics outsourcing less often than companies in other world regions. The proportion of the types of services employed is also quite different. While in other regions companies increase the use of advanced 3PL services such as reverse logistics, transportation planning and management, customer services, supply chain consultancy services, fleet management, etc., Czech companies usually outsource only basic logistics activities such as transportation, warehousing or customs brokerage.

The reasons for logistics outsourcing are the same in both cases of domestic and foreign companies. The most important interests are lower costs and assistance in the areas where they lack their own capacities. The statistical testing showed just an average dependence between the areas of logistics outsourcing and the main reasons for outsourcing logistic activities. Therefore, it is not possible to strictly say that some logistic activities should be outsourced and the other ones not. It depends on many other factors. The mixed system combining the use of in-house and third party facilities is the most suitable one for the majority of Czech manufacturing companies as the respondents of qualitative study confirmed.

However, as the sample was very limited and it showed quite strong dependence (up to $50 \%$ ), the research in this area will continue in order to gather additional data from more respondents. The present study is part of more complex logistics research being conducted by the authors. In future work, we aim to focus on actual trends in logistics, as well as the main problems of internal logistics and production planning and their impact on a company's performance, which will be tested by appropriate statistical tools.

Acknowledgements

The authors would like to thank the Internal Grant Agency of FaME TBU No. IGA/FaME/2013/006 (Actual Trends in Business Logistics and their Impact on the Quality of Production Planning) for financial support to carry out this research.

\section{References}

1. Aktas, E., Agaran, B., Ulengin, F., \& Onsel, S. (2011). The use of outsourcing logistics activities: The case of Turkey. Transportation Research, Part C, 19 (5), 833-852. DOI: http:// dx.doi.org/10.1016/j.trc.2011.02.005

2. Bali, O. et al. (2015). A Multi-Period Decision Making Procedure Based on Intuitionistic Fuzzy Sets for Selection Among Third-Party Logistics Providers. Journal of Multiple-Valued Logic and Soft Computing, 24 (5-6), 547-569.

3. Bajec, P. (2013). The Possibility of Developing Intelligent Logistics Outsourcing in Slovenia. Transport Journal, 28 (3), 244-255. DOI: 10.3846/16484142.2013.829520

4. Bjornar, A. et al. (2008). Outsourcing of logistics activities in a complex supply chain: a case study from the Norwegian oil and gas industry. International Journal of Procurement Management, 3 (1), 280-296. DOI: 10.1504/IJPM.2008.017526 
5. Idnes. (2013). Outsourcing logistiky zvyšuje efektivitu firmy. Retrieved June 3, 2013, from http://sdeleni.idnes.cz/outsourcing-logistiky-zvysuje-efektivitu-firmy-f7m-/eko-sdeleni. aspx?c=A110112_120506_eko-sdeleni_ahr

6. Bobák, R., \& Pivodová, P. (2011). Výrobní a logistická výkonnost českých a slovenských podniků. In Sborník přednášek a příspěvků Logistika v teorii a praxi II (pp. 164-169). Zlín (Czech Republic): Univerzita Tomáše Bati ve Zlíně

7. Capgemini. (2013). 2013 Third-Party Logistics Study. Capgemini Consulting.

8. Corbett, M.F. (2004). Outsourcing Revolution: Why it Makes Sense and How to Do it Right. Chicago: Dearborn Trade Publishing.

9. Eurostat. (2013). Small and medium-sized enterprises. Retrieved June 3, 2013, from http://epp. eurostat.ec.europa.eu/portal/page/portal/ european_business/special_sbs_topics/small_ medium_sized_enterprises_SMEs

10. Gadde, L.E., \& Hulthén, K. (2009). Improving logistics outsourcing through increasing buyer-provider interaction. Industrial Marketing Management, 38, 633-640.

11. Grossler, A. et al. (2013). Differences in outsourcing strategies between firms in emerging and in developed markets. International Journal of Operations \& Production Management, 33 (3-4), 296-321. DOI: $10.1108 / 01443571311300791$

12. Hätönen, J., \& Eriksson, T. (2009). 30+ years of research and practice of outsourcing - Exploring the past and anticipating the future. Journal of International Management, 15 (2), 142-155 doi:10.1016/j.intman.2008.07.002

13. Hong, J. et al. (2004). Logistics outsourcing by manufacturers in China: a survey of the industry. Transportation Journal, 43 (1), 17-25.

14. Hsiao, H. I. et al. (2010). A classification of logistic outsourcing levels and their impact on service performance: Evidence from the food processing industry. International Journal of Production Economics, 124 (1), 75-86. doi:10.1016/j.ijpe.2009.09.010

15. Li-jun, Z. (2012). Research on analysis and control of enterprise logistics outsourcing risks. Energy Procedia, 17, 1268-1273. DOI: http://dx.doi.org/10.1016/j.egypro.2012.02.237

16. Marshall, D., McIvor, R., \& Lamming, R. (2007). Influences and outcomes of outsourcing: Insights from the telecommunications industry. Journal of purchasing and supply management, 13 (4), 245-260. doi:10.1016/j.pursup.2007.07.001

17. Mojsilović et al. (2007). A Logistic Regression Framework for Information Technology Outsourcing Lifecycle Management. Computers and Operations Research, 34 (12), 3609-3627. doi:10.1016/j.cor.2006.01.018

18. Stojanovic, D. (2012). Paradoxes and Opportunities in Logistic Outsourcing Research. Promet-Traffic \& Transportation Journal, 24 (6), 525-533. DOI: 10.7307/ptt.v24i6.1204

19. Sun, J., \& Zheng, J. (2008). Research on the Model of Early-Warning of Logistics Outsourcing Risks Based on Four Phases. In Proceedings from International Conference on Wireless Communications, Networking and Mobile Computing 2008 (pp. 1 - 5). Dalian (China): IEEE. DOI: 10.1109/WiCom.2008.2468 
20. Tsai, M. Ch. et al. (2012). The dark side of logistics outsourcing - Unraveling the potential risks leading to failed relationships. Transportation Research Part E: Logistics and Transportation Review, 48 (1), 178-189. DOI: 10.1016/j.tre.2011.07.003

21. Wan, S. P. et al. (2015). An intuitionistic fuzzy linear programming method for logistics outsourcing provider selection. Knowledge-based Systems, 82, 80-94. DOI: 10.1016/ j.knosys.2015.02.027

22. Wilding, R., \& Juriado, R. (2004). Customer Perceptions on Logistics Outsourcing in the European Consumer Goods Industry. International Journal of Physical Distribution and Logistics Management, 34 (8), 628-644. DOI: 10.1108/09600030410557767

\section{Contact information}

Ing. Denisa Hrušecká, Ph.D.

Tomas Bata University in Zlin, Faculty of Management and Economics Mostni 5139, 76001 Zlin, Czech Republic

Email:brusecka@fame.utb.cr.

Ing. Lucie Macurová, Ph.D.

Tomas Bata University in Zlin, Faculty of Management and Economics Mostni 5139, 76001 Zlin, Czech Republic

Email:macurova@fame.utb.cz.

Ing. Eva Juričková, Ph.D

Tomas Bata University in Zlin, Faculty of Management and Economics Mostni 5139, 76001 Zlin, Czech Republic

Email:jurickova@fame.utb.cz.

Ing. Leona Kozáková

Tomas Bata University in Zlin, Faculty of Management and Economics Mostni 5139, 76001 Zlin, Czech Republic

Email:lea.kozakova@seznam.cz. 